\title{
Holy Mutability: Religionsgeschichte and Theological Ontology
}

\author{
Collin Cornell \\ Emory University, Atlanta, GA 30322 USA \\ collin.cornell@emory.edu
}

\begin{abstract}
The Christian community characteristically confesses the constancy of God. But historians of religion know by contrast that the deity Yhwh evolved over time. How might scholars who belong to both these camps negotiate the disconnect? This essay seeks an answer by staging a moment of complementarity between Religionsgeschichte and от theology. First it considers two cases in which the discourses of each discipline mirror one another by narrating the same event of deity change: Ps 82 and Yhwh's greater mercy through exile. Second, it provides a sampler of two theological ontologies that countenance "holy mutability": the open theism of Terence Fretheim and the evangelical historicism of Eberhard Jüngel.
\end{abstract}

\section{Keywords}

history of religions - theological ontology - exile - prophets - Terence Fretheim Eberhard Jüngel - divine wrath - divine mercy

Thou changest not, Thy compassions they fail not, As Thou hast been, Thou forever wilt be...

Morning by morning new mercies I see. ${ }^{1}$

1 Thomas Chisholm, “Great is Thy Faithfulness.” (C) 1923, Ren. 1951 by Hope Publishing Co. 
"Thou changest not," says the hymn — and yet deities change. This much is a truism of scholarship on the history of religions. Where the Christian community characteristically says to God, "As thou hast been, thou forever wilt be," the historian of religion knows by contrast that the deity Yhwh evolved over time. This creates a disconnect for those members of the theological academy who belong to both camps. The present essay is offered in service to them. It cannot hope fully to resolve so vexed an issue, or even to interest historians of religion who operate without theological commitments. Its aim is more modest: to stage a moment of rapprochement between Religionsgeschichte and a theologically realist version of (Old Testament) theology. Its audience, obviously, will include only scholars for whom such theological realism is pressing.

This proposed moment of complementarity between the two disciplines requires two building blocks. First, the discourses of each discipline must mirror one another. At the level of speech, the two must come into symmetry. As will be seen, this is already hurdle enough, since Religionsgeschichte typically traffics in development and dynamism and theology in eternals and constants ("forever wilt be"). Nonetheless, sometimes theology, too, may speak of deity change; in Karl Barth's words, "there is such a thing as a holy mutability in God." The first section below isolates two cases in which sentences of Religionsgeschichte and (от) theology run parallel by narrating the same events of deity change.

The second building block is ontology. For a theologically realist version of (от) theology, it is not enough to compare the two disciplines on the formal level only, as if merely to compare the grammars of two research areas. Rather, the present essay must move from discourse to ontology: ${ }^{3}$ to posit ways in

$2 C D$ II $/ 1,496$. Note that, according to Bruce L. McCormack, "[Barth's] proximity to [open theism in this quotation] is to be explained, in part at least, by the fact that Barth has not yet arrived at his most mature conception of the being and essence of God... At the heart of the tensions resident in Barth's doctrine of God in Church Dogmatics II/1, then, lies the fact that Christology does not yet control his theological ontology" ("The Actuality of God: Karl Barth in Conversation with Open Theism," in Engaging the Doctrine of God: Contemporary Protestant Perspectives, ed. Bruce L. McCormack [Grand Rapids, MI: Baker Academic, 2008], 185-242, here 232, 234). Cf. also idem, "Divine Impassibility or Simply Divine Constancy? Implications of Karl Barth's Later Christology for Debates over Divine Impassibility," in Divine Impassability and the Mystery of Human Suffering, ed. James F. Keating and Thomas Joseph White, O.P. (Grand Rapids, MI: Eerdmans, 2009), 150-187.

3 Or, in the signature terminology of Brevard Childs, from verbum (witness) to res (reality). Philip Sumpter has made these two terms the lodestar of his approach to Childs's hermeneutics. See his The Substance of Psalm 24: An Attempt to Read Scripture after Brevard S. Childs, Lнвотs 6 oо (New York: T\&T Clark, 2015), 1-56; also idem, "The Trinity and the Canonical Process," ThT 72 (2016): 379-397. 
which sentences of (от) theology, at the point of their parallelism with sentences from Religionsgeschichte, could count as realist; or, nonfictional. Because the discourse of (От) theology mirrors Religionsgeschichte when narrating deity change, it will be necessary to find examples of theological ontology that can accept "holy mutability." The second section below presents two such ontologies; a sampler, as it were, of theological possibilities preliminary to disciplinary rapprochement.

An example from a neighboring discipline will illustrate what is meant in this essay by "discourses running parallel" as well as by "theological realism" (or "nonfictiveness"). Historians write about the religion of Ugarit that its deity, Ba'al, rose to mythological prominence as a reflex of political developments there: "the rise of Ba'al as depicted in the [Baal] cycle may reflect the rise of Ba'al's popularity in the city, perhaps due to a change in dynasty." Ba'al on this read is a human concept riding the tide of eminently human forces like political succession. Conceptions of Baal changed, and contemporary historians frame this change in terms of political turnover. ${ }^{5}$ Alternately, one must assume that for his Late Bronze Age raconteurs, Ba'al's rise to mythological prominence was the result of Ba'al's own initiative. Ba'al on this read is an agent, as responsible for his own change in status as any enterprising human dynast here below.

Langdon Gilkey once located the difference between the Bible and its modern commentators at the level of syntax: "[T]hough God is the subject of all the verbs of the Bible, Hebrew religious faith and Hebrew minds provide the subjects of all the verbs in modern books on the meaning of the Bible." ${ }^{6}$ His syntactic observation applies, mutatis mutandis, to the case of Baal above. Historians of Ba'al place humans and human forces in the grammatical subject position, while Bronze Age theologians of Baal place god(s) in the grammatical subject position. Diagrammatically:

Syntax 1: Ugaritic kings [human subject] made Ba'al prestigious.

Syntax 2: Ba'al [divine subject] conquered the deity Yamm and so rose to power.

4 Mark S. Smith and Wayne T. Pitard, The Ugaritic Baal Cycle, Vol 2: Introduction with Text, Translation, and Commentary of KTU/CAT 1.3-1.4, VTSup 114 (Leiden: Brill, 2009), 46.

5 (Socio-)politics is not the only explanatory register that historians of religion employ, but they invoke it frequently. See the cautions of John C. Gibson and Robert Oden about this operation, of painting intellectual changes onto the chassis of political history (John C. Gibson, "The Theology of the Ugaritic Baal Cycle," UF 18 [1986]: 313-39; Robert Oden, "Theoretical Assumptions in the Study of Ugaritic Myths," Maarav 2 [1979]: 43-63).

6 Langdon Gilkey, “Cosmology, Ontology, and the Travail of Biblical Language," JR 41 (1961): 194205, here 197. 
These sentences are symmetrical; they name the same deity and narrate the same progression in his status, even as they also place two different agents in the lead grammatical role. The two sentences also narrate a change. They are not stative, referring to an enduring condition (like saying, "Ba'al is mighty," e.g., $\mathrm{KTU}^{3} 1.6$ vi $17,19,20$ ), but dynamic. The condition resulting from the narrated action is different from that at which it began.

Historians and theologians of Yhwh speak about him with the same syntactic markers that distinguish historians from devotees of Baal. These two discourses also characteristically place different agencies in the subject position. (от) theology fronts God as subject, whereas Religionsgeschichte fronts humans and human forces. But these two disciplines also occasionallyarguably_-describe the same events of deity change. In this sense, they "run parallel," discursively.

The example of Baal is also instructive with regard to the meaning of "(non) fictiveness." Presumably the first author(s) and audiences of the mythic texts about Ba'al and his rise to kingship took them as nonfictional. It is impossible to know how an Ugaritian would have answered questions about the relation of a mythic text to the (extra-textual) deity whose exploits it celebrates. But one can safely assume that the mythic texts about Ba'al, whatever else their function, were seen as telling truthfully about a deity active in the world "out there" and not, as it were, alive only in imagination for the duration of the texts' recital. $^{7}$

For its first authors and audiences, too, от texts were presumably taken as nonfictional, in this general sense. ${ }^{8}$ But this difference obtains: no devotees of Ba'al exist today who consider sentences about Ba'al nonfictional; contemporary students of the Ba'al cycle today regard it as artefactual and decidedly not realist. We do not expect to encounter the deity Baal outside of our reading experience. This is not so for the от. At least some forms of (от) theology take sentences about Yhwh as, in some sense, nonfictional: indicating or evoking an extra-textual being, i.e., the LORD. Some of us do, indeed, expect to encounter

7 This is demonstrated, among other examples, by the small stone anchors excavated in the temple of Ba'al at Ugarit, given as votive offerings by grateful seafarers (Honor Frost, "Anchors Sacred and Profane," in Arts et industries de la pierre, ed. Marguerite Yon, Ras-Shamra Ougarit IV (Paris: Éditions Recherche sur les Civilizations, 1991], 355-410). No one gives votive offerings to a fictional character.

8 The sense must be general because there are many genres in the от, several of which it would be odd to speak of (without qualification) as nonfictional, e.g., "nonfictional lyric poetry." Also, there may well be historical fiction in the от (on this, see John Goldingay, Models for Scripture [Grand Rapids, MI: Eerdmans, 1994], 61-76). However, even the lyric poems and fictional novellae of the Bible indicate or evoke an extra-textual being, Yhwh, and so in this general sense still qualify as nonfictional. 
this God outside of our reading experience. ${ }^{9}$ This is the constructive form of (от) theology with which the present essay concerns itself. ${ }^{10}$

\section{Discursive Case Studies}

To reach a moment of rapprochement between Religionsgeschichte and (от) theology, sentences from their corpora must come into symmetry: by describing the same event of deity change. But it is difficult to discern if and when (от) theology and Religionsgeschichte do, in fact, deal with the same happenstance. For example, scholarship on the history of Israelite religions speaks often of the emergence of monotheism. Many sentences in such scholarship describe a change that took place in the conception of Yhwh over time (with human forces as their subject):

The innovative centralization of national worship was also part of the process leading to monotheistic Yahwism, as it encouraged a single national deity and discouraged local manifestations of deity. The royal unification of national life-both political and religious-helped to achieve political and cultic centralization. ${ }^{11}$

9 Some readers might object to this formulation, of "encountering Yhwh extra-textually." If, in Lindbeck's famous axiom, "Scripture absorbs the world," no encounter with Yhwh (or anything else) ought really be "extra-textual." I sympathize with this perspective, but at the same time aspire to a realist ontology. An example is found in the work of Eberhard Jüngel, about whose opus John Webster writes, "it recommends a 'realist' account of our knowledge of God, in which human thinking about God is brought about not so much by human inventiveness as by an initiative beyond itself" ("Jesus' Speech, God's Word: An Introduction to Eberhard Jüngel (I)," ChrCent 112 [1995]: 1174-78, here 1177). Cf. the helpful taxonomy of realism and anti-realism in от theology by Jaco Gericke, "Realism and Non-Realism in Old Testament Theology: A Formal-Logical and Religious-Philosophical Assessment," OTE 19 (2006): 47-57.

10 Naturally, there are other forms of от theology, which see their task as descriptive (only) and situate themselves as subdisciplines of history or sociology; see, for example, John J. Collins, "Is a Critical Biblical Theology Possible?" in The Hebrew Bible and its Interpreters, ed. William Henry Propp, Baruch Halpern, and David Noel Freedman, BJsucsD 1 (Winona Lake, IN: Eisenbrauns, 1990), 1-17.

11 Mark S. Smith, Early History of God: Yahweh and the Other Deities in Ancient Israel (San Francisco: Harper and Row, 1990), 148. 
Or, more diagrammatically:

Syntax 1: Nationalization [human subject] helped to make Yhwh the sole deity of Israelite religion.

But for the most part, the от preserves no memory of this sea-change from a plurality of deities to only one. Perhaps only one text narrates a change from the one to the other, representing the theological stop motion footage between, say, the henotheism of Exodus and the monotheism of Second Isaiah. ${ }^{12}$ The enigmatic Ps 82 thus reads:

I said, "You are gods,

And all of you are sons of the Most High.

"Nevertheless you will die like men

And fall like any one of the princes." (NASB)

The speaker-apparently God-utters performative speech. Its effect is to demote the gods addressed from divinity to mortality. ${ }^{13}$ The resultant situation is one of divine singularity. Yhwh-here Elohim—alone is divinely immortal. The whole can be restated in syntax running parallel to the religion-historical sentence above.

Syntax 2: Yhwh [divine subject] demoted the other gods for failing to observe justice, making himself the sole deity.

In an extended and shadowy sense, the above sentences concern the "same" event. Even if the second, theological sentence is not time-stamped in the same way as the first, the two both speak of a progression in Yhwh's status from being one among several gods to being the one and only. They also narrate a dynamic change rather than speaking statively. They are, then, symmetrical, even as they place differing agents in the grammatical lead role.

Another and perhaps stronger example when the discourses of Religionsgeschichte and (От) theology run parallel concerns the impact of defeat on the personality of Yhwh. Some recent research in both the history

12 For one recent treatment of Psalm 82 along this line, see Seth L. Sanders, "When the Personal Became Political: An Onomastic Perspective on The Rise of Yahwism," HeBAI 4 (2015): 59-86, here 64-66.

13 See Brent A. Strawn, "The Poetics of Psalm 82: Three Critical Notes Along With a Pleas for the Poetic," $R B 121$ (2014): 21-46, here 33. 
of religions and (от) theology concurs that national defeat reshaped the personality of Yhwh, turning him towards unprecedented mercy. ${ }^{14}$ From the religionsgeschichtliche side, this claim can be summed up like so:

1. Yhwh was worshipped as the patron deity of Israelite and Judean state religion, and his profile as a deity was basically comparable to the patron deities of other Levantine state religions. The deity of "Zion theology" was, like the deity Kemosh of the Mesha stele, kingly: a god of power and might; and as a patron deity, figured in a fundamental symbiosis with the human king and the state. ${ }^{15}$

2. Because of experience (s) of devastation and exile, Yhwh's wrath was interpreted more severely than any analogous deities. The deity of several от prophetic books threatened completely to destroy his own societyshattering the symbiosis of deity, king, and state, and thereby achieving a genuine theological novum relative to other Levantine theologies. ${ }^{16}$

3. This more severely wrathful Yhwh opened up new possibilities in turn for a yet more merciful Yhwh. The prophetic books also portray a deity of unsurpassed mercy. Without the (now destroyed) state-religious indices of Yhwh's favor-military success, building campaigns, national securitythe personality of Yhwh was freed up from these limits, and answered only to a devastated people's need for a God of comfort and promise. Yhwh's mercy was, in a radically unprecedented way, limit-less.

This argument affirms but also chronologically reshuffles a tension of longstanding scholarly note between the dynastic and prophetic от theological traditions. ${ }^{17}$ Eichrodt may be taken as merely the most thorough-going

14 On national defeat as a catalyst of literary (and theological) innovation, see Jacob L. Wright, "The Commemoration of Defeat and the Formation of a Nation in the Hebrew Bible," Prooftexts 29 (2009): 433-72.

15 Reinhard G. Kratz, "Reste hebräischen Heidentums am Beispiel der Psalmen," NAWG.PH 1 (2004/2): 25-65; Reinhard Müller, "Die frühe Jahweverehrung im Spiegel der ältesten Psalmen," in Anfänge und Ursprünge der Jahweverehrung, ed. Cilliers Breytenbach et al., BThZ 30 (Leipzig: Evangelische Verlagsanstalt, 2013), 89-119.

16 Reinhard G. Kratz, "Chemosh's Wrath and Yahweh's No: Ideas of Divine Wrath in Moab and Israel," in Divine Wrath and Divine Mercy in the World of Antiquity, ed. Reinhard G. Kratz and Hermann Spieckermann, FAT II/33 (Tübingen: Mohr Siebeck, 2008), 92-121.

17 See, inter alia, Bernhard W. Anderson's remarks: "these two institutions [monarch and temple], so basic to the cultures of the ancient Near East, were alien to Israel's 'root experiences' of exodus and Sinai [i.e., the conditional, Mosaic covenant]" (The Contours of Old Testament Theology [Minneapolis, MN: Fortress, 1999], 196). For perhaps the 
expositor of the common idea that from the earliest layers of Israelite religion, Yhwh's relationship to his people was gratuitous and soluble, i.e., "covenantal." In Eichrodt's words, "this [covenant relationship] is something on which God has entered freely and which he on his side may dissolve at any time."18 Israel thus lived always under the possibility that Yhwh could, in annihilating wrath, turn wholly against them. Doom was a threat built primordially into Israel's covenant with Yhwh. And so on Eichrodt's account, the theology characteristic of the monarchy_ "Zion theology" - represented a dangerous interposition, indeed, a "jeopardizing of the Yahweh covenant"19 and "an assimilation to Canaanite ways of thought." 20 This dynastic theology enlisted Yhwh "to appear as the natural ally of the national greatness."21 It made Yhwh symbiotic with the state. As such, it left Yhwh's relationship with Israel indissoluble: the anger of Yhwh could disrupt but hardly undo the nation over which he was patron.

On the basis of comparative evidences, some scholars have reversed this sequence. What Eichrodt takes an interposition, i.e., Yhwh as a characteristic state deity, this research interprets as primordial. What he sees as the most basic feature of Israelite faith, i.e., the possibility that Yhwh could terminate his relation to Israel, this research reads as a prophetic innovation. No one before Amos or Hosea had imagined that Yhwh could be so wrathful as to destroy his own king and country. Conversely, no other Levantine theology had had opportunity to proclaim the mercy of its deity so extremely as the от prophetic books. Because other Levantine deities always and ultimately supported the societies over which they were patron, they could never have promised to reconstitute a society like Yhwh did. Nor did they have need of consoling a disenfranchised people, like Yhwh did. In a very real way, then, the experiences of devastation and exile made Yhwh more merciful than he had

most (in)famous treatment of the theological tension between dynastic and prophetic blocks within the от, see George Mendenhall, "The Monarchy," Int 29 (1975): 155-70. For less oppositional negotiations of these two theological blocks, see J.J.M. Roberts, "In Defense of the Monarchy: The Contribution of Israelite Kingship to Biblical Theology," in Ancient Israelite Religion: Essays in Honor of Frank Moore Cross, ed. Patrick D. Miller, Jr. Paul D. Hanson, and S. Dean McBride (Philadelphia: Fortress, 1987), 377-96, and Ben C. Ollenburger, Zion, The City of the Great King: A Theological Symbol of the Jerusalem Cult, JSOTSup 41 (Sheffield: Sheffield University Press, 1987), 145-62.

19 Ibid., 1:45.

$20 \quad$ Ibid., 1:48.

21 Ibid. 
been before-and more merciful than any of his cognate patron deities in the southern Levant.

This religion-historical conclusion can be diagrammed like so:

Syntax 1: Because of the destruction of the Israelite and Judean states, от prophets [human subject] imagined Yhwh as more wrathful than any other patron deities; but they then also imagined Yhwh yet more mercifully.

Sentences of (от) theology narrate this same event, of divine destruction and wrath (against the Israelite and then also the Judean state) followed by a fresh divine resolve towards mercy. For example, in his Theology of the Old Testament, Walter Brueggemann argues for an irresolvable contradiction in the character of Yhwh, between commitment to Yhwh's own self and commitment to solidarity with Israel. Brueggemann writes on a body of от texts that pose this disjunction through a "two-stage sequence":

In a variety of texts, all situated in and reflecting on Israel's exile and anticipated homecoming, this tension is expressed as a two-stage sequence. I suggest that the first, destructive act in the sequence is derived from Yahweh's self-regard; in the second act, as though in a recovery of covenantal intentionality, Yahweh expressed fidelity to and regard for Israel. Three texts may be cited for what seems to be a rather common reading of the crisis. ${ }^{22}$

The three texts Brueggemann examines are: Jer 31:28, Isa 47:6, and Deut 4:2431. Of the Deuteronomy passage, for example, Brueggemann notes that v. 26 speaks of Israel utterly perishing from the land and v. 27 of scattering. That is, the passage first depicts Yhwh's comprehensive destructiveness towards Israel. Verse 29 describes Israel's action of seeking Yhwh "from there," from the place of their displacement in exile. Verse 31 then evokes Yhwh's mercy: "he will not abandon or destroy you or forget the covenant with your ancestors." This divine mercy seems to work in a very different direction from the wrath that precedes it. In effect, Yhwh reverses course, and replies to his own earlier destructiveness with mercy. ${ }^{23}$ Of this sequence in Deut 4, Brueggemann writes:

22 Walter Brueggemann, Theology of the Old Testament: Testimony, Dispute, Advocacy (Minneapolis, Mn: Fortress, 1997), 308.

23 Cf. Terence Fretheim: “Given God's faithfulness and the constancy of God's loving purposes, it may be that God will have to forsake God's own past in order to be true to those 
Moses [here] traces a remarkable move in the character of Yahweh... The theological dimension of the preexilic warning is that Yahweh is "a devouring fire, a jealous God" (v. 24), a God who will brook no rival and tolerate no disobedience ... were the character of Yahweh sustained into exile in continuity, we would expect Israel, in exile and beyond exile, to continue to deal with a jealous, uncompromising God. The God who is available "from there," however, is not the devouring God from preexile. In the middle of the text, in the middle of Israel's experience, and we may believe, in the middle of God's life with Israel, there is a new "there"exile. When Moses continues his testimony about the God with whom Israel has to deal, everything is changed ... what emerges in the text is a real break in God's way with Israel, as such a real break in God's way of being God ... [T] hat break makes visible the emergence of a God of compassion whom Yahweh has not been before in this text, an emergence evoked by the Exile. ${ }^{24}$

For the purpose of the present essay, two points are important: first, the pattern under discussion, of Yhwh's annihilating wrath moving to (even greater) mercy is, according to Brueggemann, canonically widespread. ${ }^{25}$ Unlike the example of Ps 82, sentences narrating Yhwh's wrath followed by Yhwh's mercy are not marginal to the canon. Second, such sentences are more easily located, historically. Of course, experiences of Yhwh's disfavor presumably predate the destruction of the Israelite and Judean states. It wasn't as though Yhwh had never been angry with his people before these events. But the present essay accepts that the deity's threats of total annihilation are unique to the era(s) of the Assyrian and then Babylonian invasions into the southern Levant, and so texts that envision such extreme wrath are locatable to that era. Unlike Ps 82, in the case of Yhwh's turn to greater mercy after wrath, there is more assurance

purposes, indeed for the sake of God's own name" ("The Repentance of God: A Key to Evaluating Old Testament God-Talk," HBT 10 [1988]: 47-70, here 6o). For more on divine repentance, see Jean-Pierre Sonnet, "God's Repentance and 'False Starts' in Biblical History (Genesis 6-9; Exodus 32-34; 1 Samuel 15 and 2 Samuel 7," in Congress Volume Ljubljana 2007, ed. André Lemaire, VTSup 133 (Leiden: Brill, 2010), 469-94.

24 Walter Brueggemann, "A Shattered Transcendence? Exile and Restoration," in Biblical Theology: Problems and Perspectives, ed. Steven J. Kraftchick, Charles D. Myers, Jr., and Ben C. Ollenburger (Nashville: Abingdon Press, 1995), 169-82, here 174.

25 Brueggemann also cites the flood story of Gen 6-9 as following a parallel sequence ("A Shattered Transcendence," 178). Another of his essays notes the same movement in Yhwh's character, from anger to compassion, in Hosea ("The Recovering God of Hosea," $H B T 30$ [2008]: 5-20). 
that the canonical sentence and the religionsgeschichtliche sentence describe the "same" event. These kinds of theological statements can be diagrammed as follows:

Syntax 2: Yhwh [divine subject] acted in wrath to destroy (the Israelite and Judean states), but then chose to be yet more merciful than he had ever been before.

Several other observations about the above theological sentence will become relevant in due course. First, the sentence above contains an irreversible linearity. God's wrath and mercy are not (here) two gnomic attributes, but two points on a historical line. Second, the sentence narrates a sequence of divine decisions that seem to work oppositely. If the second decision had been effective initially, the first divine decision would not have occurred. The two acts are thus genuinely "bipolar." 26 Third, this means that there is an $\dot{\varepsilon} \varphi \dot{\alpha} \pi \alpha \xi$ quality to the whole sequence. ${ }^{27}$ In the от, Yhwh's mercy that follows the exile does not threaten to regress back to wrath. Despite the fact that threats of divine wrath and judgment through exile stand in the canon, their force seems largely retrospective; they do not act as a conditional clause asterisked onto the grand prophetic promises of resettlement in the land and renewed national life. ${ }^{28}$ The theological sentence above is irreversibly linear, genuinely bipolar, and $\dot{\varepsilon} \varphi \dot{\alpha} \pi \alpha \xi$.

26 Brueggemann uses this word to describe the "deep incongruity" the от depicts between God's character as punishing violators and exercising mercy ("A Shape for Old Testament Theology, I: Structure Legitimation," repr. in Old Testament Theology: Essays on Structure, Theme, and Text, ed. Patrick D. Miller, Jr. [Minneapolis, MN: Fortress, 1992], 1-21, here 4).

$27 \dot{\varepsilon} \varphi \dot{\alpha} \pi \alpha \xi$ is a term that occurs five times in the New Testament, meaning "once and for all."

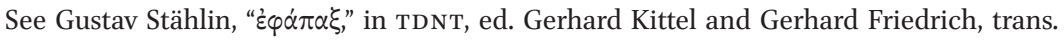
Geoffrey W. Bromiley, 10 vols. [Grand Rapids, MI: Eerdmans, 1964], 1:383).

28 See, for example, the observation of Ronald E. Clements in his classic essay, "Patterns in the Prophetic Canon": "[The prophetic] message concerned the destruction and restoration of Israel, but special emphasis was attached to the latter. This was because this restoration was still looked for in the future, while the destruction was believed to have already taken place" (in Canon and Authority: Essays in Old Testament Religion and Theology, ed. George W. Coats and Burke O. Long [Philadelphia: Fortress, 1977], 42-55, here 45). 


\section{Ontological Case Studies}

The section above sampled two cases in which the discourses of Religionsgeschichte and (от) theology parallel one another by narrating the same event of deity change. This kind of demonstration is necessary for showing the complementarity of Religionsgeschichte and (от) theology; each discipline's speech must sometimes mirror the other's. However, this comparison remains at the level of discourse only. As such, it cannot claim truly to stage a rapprochement between Religionsgeschichte and a theologically realist version of (от) theology. Proposing a moment of correspondence between these two requires that the present essay also consider ontology: it must answer the question of how dynamic theological sentences like the one above about Yhwh's decision for greater mercy can qualify as nonfictional.

A major difficulty for this task is the fact that classical theology does not underwrite the nonfictiveness of dynamic theological sentences. To the contrary, it mostly empties such sentences of their claim to nonfictiveness. Exegetes within the Jewish and Christian traditions have by necessity negotiated sentences from the от that speak of divine repentance or divine mutability. But because of their commitment to a doctrine of divine immutability, they have often given only a propadeutic place to dynamic scriptural language for God. ${ }^{29}$ Such rhetoric may yet instruct and edify, but it is not to be "crudely ascribed to divine things." ${ }^{30}$ In effect, these statements become a kind of fiction: biblical descriptions of God as mutable live only in the imagination for the duration of their contemplation, and do not correspond (much) to any divine referent. They are not wholly fictional, since they still name the extratextual being, Yhwh. But at the same time, their referential power is almost wholly circumscribed. ${ }^{31}$

29 "Propadeutic" in the sense of, preparing its audience to move on to more refined, less pictorial forms of contemplation. So Aquinas: "For the minds of those given the revelation are not allowed to remain arrested with the images. They are lifted up to their meaning" (Summa Theologica, Questions on God, ed. Brian Davies and Brian Leftow, Cambridge Texts in the History of Philosophy [New York: Cambridge University Press, 2006], 16).

$30 \quad$ Ibid., 17.

31 This might not be a problem; as mentioned earlier in the present essay (n. 8), the Bible contains genres such as lyric poetry or fictional novella whose only claims to ontological realism consist in their naming of the extra-textual being, Yhwh. However, especially given the wide distribution of dynamic theological sentences about Yhwh's greater mercy after devastation (e.g., most prophetic books), perhaps the classical approach curtails the 
This line of thinking, whatever its general merits, greatly reduces the potential complementarity between sentences of Religionsgeschichte and sentences of theology. It renders their parallelism formalistic only. Their discourses may mirror one another, but at the level of ontology, the two disciplines remain oblique.

Perhaps this situation is satisfactory to its various constituencies. But the present essay seeks a moment of rapprochement between the two disciplines, which converge while describing an event of deity change. Because of its concern for a theologically realist (От) theology, this means looking for theological ontologies that can countenance "holy mutability." The section below sketches two theological ontologies that do not limit the referential power of dynamic theological sentences but enable them to count as nonfictional. The first ontological case study describes the open theism of Terence Fretheim; the second describes the "evangelical historicism" of Eberhard Jüngel..$^{32}$ Both of these brief overviews refer back to the case study of Yhwh's greater mercy through defeat and exile.

\section{Open Theism: Terence Fretheim}

Terence Fretheim's writings are pervasively theocentric; the being of God and God's relation to the world are focal points of his corpus. From his 1984 book on The Suffering of God to his 2005 God and the World in the Old Testament, he has treated widely of theological language about divine mutability, and affirmed its correspondence with the extra-textual being of God: "To speak of God as the one who repents, with the basic idea of reversal and change, does have some basic points of continuity with the way God actually relates to the world." ${ }^{33}$

The core of Fretheim's conviction about the God-world relationship is that "the world is not only affected by God; God is also affected by the world." 34 One of Fretheim's bywords is integrity. God "enters into a relationship of integrity

nonfictiveness of relatively toо тисh от literature-if, on the whole, the от is to be considered nonfictional.

These theologians were selected because their works are thoroughly theocentric; ontologically realist; and alternative to classical theology. They are also both Lutheran and notably indebted to Luther's theologia crucis.

Terence E. Fretheim, The Suffering of God:An Old Testament Perspective, овт (Philadelphia: Fortress, 1984), 8.

34 Ibid., 35 . 
with the world ... and both the world and God are affected by that linkage."35 The integrity of God's relationship to creation entails divine affectability: divine openness to input from creatures endowed with autonomy. It also entails divine temporality: "God is in time," such that there is a before and after in the divine person. ${ }^{36}$ Who God is later differs from who God was formerly.

Two important qualifications on this claim for "holy mutability" are quickly apparent in Fretheim's writings: one, God's affectability by the world is selfundertaken, "a free act of self-limitation." 37 God does not stand in a relationship of affectability eo ipso. Fretheim here distinguishes himself from process theism, according to which God grows through God's history with the worldnot by God's choice, but essentially, as a function of who God is from the outset. ${ }^{38}$ Second, God's affectability is also limited by the constancy of God's purpose. God is not capricious. For Fretheim, God's will to save is steadfast and enduring. ${ }^{39}$

With regard to the case study above, Fretheim's theological ontology would allow for statements about Yhwh's decision for greater mercy after the destruction of exile to obtain - nonfictionally. In fact, much of what Fretheim writes of the flood story in Gen 6-9 applies just as well to the cataclysmic divine judgment of exile and Yhwh's changed resolve thereafter. As with the flood, so with the experience(s) of exile: Yhwh first acts (though sorrowfully) to effect destruction. After punishment has run its course, Yhwh then appears to reverse course: Yhwh promises not to do again what Yhwh did at first. The very same human condition that at first moved Yhwh to judgement (see Gen 6:5) at the end of the flood story (see Gen 8:21) moves Yhwh to an act of divine self-limitation. Yhwh promises never again comprehensively to destroy. God's history in the flood is also irreversibly linear, genuinely bipolar, and $\dot{\varepsilon} \varphi \alpha \dot{\tau} \pi \xi$. Thus Fretheim:

What God does here recharacterizes the divine relation to the world. God softens the workings of divine judgment and promises an orderly cosmos

35 Terence E. Fretheim, "God (OT View of)," in NIDB, ed. Katherine Doob Sakenfeld, 5 vols. (Nashville: Abingdon, 2006), 2:603-18, here 611.

36 Fretheim, Suffering, 42, 43.

37 Ibid., 58 .

38 On this difference, see Michael J. Chan and Brent A. Strawn, "Introducing Fretheim: His Theology and His God," in What Kind of God? Collected Essays of Terence E. Fretheim, ed. Michael J. Chan and Brent A. Strawn, Siphrut 14 (Winona Lake: Eisenbrauns, 2015), 3-17, here 4,5 .

39 Fretheim, "The Repentance of God," 63. 
for the continuation of life. God will never do this again! God is the one who has changed between the beginning and the end of the flood, not human beings. ${ }^{40}$

Fretheim's theological ontology permits a rapprochement between sentences of Religionsgeschichte and dynamic theological sentences, because Fretheim posits a view of God that ensures the nonfictiveness of dynamic theological language. The two diagrammed sentences could each stand as nonfictional:

Syntax 1: Because of the destruction of the Israelite and Judean states, от prophets [human subject] imagined Yhwh as more wrathful than any other patron deities; but they then also imagined Yhwh yet more mercifully

Syntax 2: Yhwh acted in wrath to destroy (the Israelite and Judean states), but then chose [divine subject] to be yet more merciful than he had ever been before.

Doubtless some readers will quail at Fretheim's theological ontology. See, for example, Brevard Childs's scandalized reaction: "[Fretheim says] God is unchangeable in certain respects, but God changes in the light of his relationship with the world. My initial response is to dismiss this [idea] as an egregious intrusion of modern American Process Theology!"41 The heart of Childs's (and others') objection to Fretheim's theological ontology is the threat it poses to divine freedom. Childs is concerned that Fretheim's ontology "strip[s God] of sovereignty."42 To which Fretheim would reply, God has exercised divine freedom-precisely by choosing to enter into relationship of ongoing reciprocity with the world. ${ }^{43}$ The goal of the present essay is not, however, finally to adjudicate between the two theological ontologies on offer here, but only to

40 Terence E. Fretheim, “Commentary on Genesis 9:8-17," Working Preacher (March 1, 2009), http://www.workingpreacher.org/preaching.aspx?commentary_id=253. Brevard S. Childs, Biblical Theology of the Old and New Testaments: Theological Reflection on the Christian Bible (Minneapolis, MN: Fortress, 1993), 357.

42 Ibid.

43 Fretheim, Suffering, 35, 36. Cf. C. Kavin Rowe: "where our hermeneutics differ from Childs's, we may reasonably expect to find differences in how we conceive of the doctrine of God" "The Doctrine of God is a Hermeneutic: The Biblical Theology of Brevard S. Childs," in The Bible as Christian Scripture: The Work of Brevard S. Childs, ed. Christopher R. Seitz and Kent Harold Richards, SBLBSNA 25 [Atlanta: SBL Press, 2013], 155-169, here 169 n. 18). 
provide a sampler for scholars interested in bridging the disconnect between their two languages, of theological realism and evolutionary religion-history.

\section{Evangelical Historicism: Eberhard Jüngel}

Nonetheless, for those readers that share Childs's concern, it may be possible to have their theological cake and eat it, too. There is another school of modern theology that protects divine freedom while also offering many of the same advantages of Fretheim's open theism. For the purposes of the present essay, it enables dynamic theological sentences to qualify as fully nonfictional. Like Fretheim, it may then offer a moment of rapprochement between the sundered dialects of Religionsgeschichte and (от) theology. This theological school is what R. Michael Allen calls "evangelical historicism." ${ }^{44}$ Allen's theological tagis idiosyncratic, but it helpfully summarizes the two lead features of the theological ontology in question.

The being of God in such theological discourse is "evangelical" in the sense of taking the "the gospel story" of Jesus Christ, and especially of his death and resurrection, as its lodestar. Eberhard Jüngel writes of evangelical theology that it "does not desire to be lacking in presuppositions, but rather implies certain decisions in its approach." ${ }^{25}$ One of the already-made methodological decisions of evangelical theology is that "the task of thinking God as God is steered by the reality of the biblical texts," ${ }^{46}$ and not just any biblical texts, but especially those that speak of the "unique relationship between God and Jesus Christ." ${ }^{47}$ This means that, like Fretheim, evangelical historicism takes the Bible as its basic working material for thinking through the identity of God. Unlike Fretheim, though, evangelical historicism privileges the biblical texts that rehearse the story of Jesus Christ. That story Jüngel frames especially in terms of "God's involvement with nothingness."48

Second, the being of God in this theological discourse is "historicist": in Allen's words, evangelical historicism "construe[s] the divine life as not merely

44 R. Michael Allen, Justification and the Gospel:Understanding the Contexts and Controversies (Grand Rapids, MI: Baker Academic, 2013), 81. Cf. Scott R. Swain's use of the term in The God of the Gospel: Robert Jenson's Trinitarian Theology (Downers Grove, IL: IVP Academic, 2013), 63 .

45 Jüngel, $G M W, 154$.

46 Ibid., 155 .

47 Ibid., 157 .

48 Ibid., 218. 
manifested but also constituted by the events of the gospel story."49 Or, again, in Jüngel's epigram, "God happens"; more specifically, "God happens as love in the death of Jesus." 50 Among other things, this statement means that "history and also time are asserted to be the place for the thinkability of God." ${ }^{51}$ Like Fretheim, evangelical historicism holds that "God appears as God within the dimension of historical factuality," including also its temporality. ${ }^{52}$

Evangelical historicism maintains the same qualifications on "holy mutability" as Fretheim. It posits that the historicity of God's being is the result of God's own decision and not, as in process theology, merely a given of God's condition. Jüngel takes up Barth's claim that "God reveals himself as the one who loves in freedom." ${ }^{53}$ This divine freedom consists in a lack of external compulsion. For Jüngel, nothing external to God required the (historical) event of God's self-giving love, since this would effectively evacuate it of its character as love. "Love is based on God, because apparently he alone can start the event of love, initiate it, because he alone can begin to love without any reason."54

Evangelical historicism differs from Fretheim in (at least) two important regards: in its delimitation of the history of God and in the unconditionality of its divine freedom. As mentioned, for evangelical historicism, Jesus Christ is the history of God—and not, as with Fretheim, the Bible taken more holistically.55 For evangelical historicism, the history of Israel is included, anticipatorily, in the history of Jesus Christ; Jüngel says of the от prophets that they are "rough sketches in story form of actions which have not yet taken place."56 For Barth and his aftercomers like Jüngel, the от witnesses to the concrete history of God in expectation, whereas the New Testament witnesses to the concrete history of God in recollection. ${ }^{57}$

49 Allen, Justification and the Gospel, 80.

5o Jüngel, $G M W, 221$.

51 Ibid., 188.

52 Ibid., 188.

53 Ibid., 327 .

54 Ibid.

55 Bruce L. McCormack faults open theists (such as Fretheim) for reading the Bible as uniformly attributable to a single divine author, rather than prioritizing "God's self-revelation in Jesus Christ" (idem, "The Actuality of God," 195).

56 Jüngel, $G M W, 310$.

$57 C D$ I $/ 2,70$. For more on this, see Otto Bächli, Das Alte Testament in der Kirchlichen Dogmatik von Karl Barth (Neukirchen-Vluyn: Neukirchener Verlag, 1987), 17-23. It is unlikely that this view will attract many in the guild of от studies, where resistance is commonplace to this (Barthian) identification of the от as an anticipatory witness to Jesus Christ. See, for example, Neil B. MacDonald: "It was only after many discussions with Christopher Seitz 
Second, and most importantly for satisfying Childs's objection, evangelical historicism differs from Fretheim in the unconditionality of its divine freedom. For Fretheim, God's own future is open, i.e., conditioned by the contingencies of world history. There are yet-unrealized potentialities inherent in the divine being. For evangelical historicism, God's future is not open. God is determined wholly by the historical event of Jesus Christ. In this way, evangelical historicism maintains with classical theism the doctrine of God as an actus purus, or pure act. ${ }^{58}$ There is no "raw material" in God awaiting further stimulus to become what it will be. Rather, "the eternal event in which God chose to be 'God for us' [in Jesus Christ] is, at the same time, the eternal event in which God gave (and continues to give) to himself his own being."59 The history of Jesus Christ exhaustively reveals and realizes whatever "possibilities" are thinkable of God's being.

Both these lines of reasoning appear to compromise the nonfictiveness of dynamic theological sentences excerpted from the от. If dynamic theological sentences from the от must be "re-routed" through the gospel story of Jesus Christ, this seemingly eviscerates their realism. If God's being does not change in response to the unfolding events of history, this seems to empty sentences about divine mutability of their referential purchase. Nonetheless, there may be room yet in this theological school for dynamic theological sentences drawn from the от to count as nonfictional. For evangelical historicism, whatever "holy mutability" pertains to God must first of all describe Jesus Christ. This kind of theological ontology would countenance theological language about Yhwh's greater mercy through exile insofar as it could construe it as an analogical echo, a repetition from beforehand, of God's own realized passability (i.e., passion) in the death and resurrection of Jesus.

In other words: if the above diagrammed theological sentence about Yhwh's greater mercy through exile can be read as a proleptic paraphrase of the gospel

over the question of the unity of the Old and New Testament that it became possible to transcend some of the classic Christocentric weaknesses in Barth's theology. As Seitz would say: we do know something about God other than through Jesus of Nazareth, Jesus Christ. We know something about the God of Israel even as this knowledge is elevated by the man Jesus" (Metaphysics and the God of Israel: Systematic Theology of the Old and New Testaments [Grand Rapids, MI: Baker Academic, 2006], xvii). Nonetheless, the above formulation is ingredient to the Barmen Declaration, which has confessional status for several ecclesial bodies (see Karl Barth, "Erklärung über das rechte Verständnis der reformatorischen Bekenntnisse in der Deutschen Evangelischen Kirche der Gegenwart," in Bächli, Das Alte Testament, 6o-63).

58 McCormack, "The Actuality of God," 214.

59 Ibid., 210. 
history of God in Jesus Christ, then such an от sentence may qualify as nonfictional, even and precisely in its dynamism. ${ }^{60}$

от theological sentence: Yhwh acted in wrath to destroy (the Israelite and Judean states), but then (!) chose [divine subject] to be yet more merciful than he had ever been before.

Jüngel's summary of the gospel: in Jesus Christ, "God decided [divine subject] to involve the divine self with nothingness, and then (!) to determine its place, creatively."

Interpreting the first sentence as a paraphrase of the second coordinates two quite different sets of terms. ${ }^{61}$ At the same time, their convergences are tantalizing: Jüngel's sentence, like the от theological sentence, is irreversibly linear, genuinely bipolar, and $\dot{\varepsilon} \varphi \dot{\alpha} \pi \alpha \xi$. First, for both the history of Yhwh through exile and the history of Jesus Christ, there is an irreversible linearity. They are both distinctively (in Brueggemann's phrase) "two-staged." It would thus be a misappropriation to decompose the event of Jesus' death and resurrection into two coexisting, "gnomic" attributes of the divine being. Such a move would give an independence of existence to death and nothingness, when what must be said of them is that they are negated. ${ }^{62}$ Nothingness has a place-in the past. The sequentiality of God's "involvement with nothingness" in the death of Jesus and God's "determination of nothingness" in his resurrection is irreversible. These events, in their linearity, determine God's being. Insofar as they are two different events in a row, then it may be accurate for evangelical historicism to

6o This is not so different a correlation from what Philip Sumpter attempts with Psalm 24 and "Jesus History" (The Substance of Psalm 24, 239-46), only drawn to a different scale, i.e., the pattern of the prophets. Cf. Donald E. Gowan, Theology of the Prophetic Books: The Death and Resurrection of Israel (Louisville, KY: Westminster/John Knox, 1998).

61 And yet, not entirely different. See the New Testament's application of Hosea 6:2, referring to the corporate restoration of Israel "on the third day" after judgment, to the resurrection of Jesus (Mark Proctor, “'After Three Days He Will Rise': The (Dis)Appropriation of Hosea 6:2 in the Markan Passion Predictions," in Biblical Interpretation in Early Christian Gospels, Vol 1: The Gospel of Mark, ed. Thomas R. Hatina, LNTs 304 [New York: T\&T Clark, 2006], 131-150). Intriguingly, the testaments are also symmetrical in that restoration belongs far less (if at all) to the realm of the publically observable than do the catastrophes of exile and crucifixion.

62 Dietrich Bonhoeffer, Creation and Fall: A Theological Interpretation of Genesis 1-3, trans. John C. Fletcher (New York: MacMillan Publishing Company, 1959), 16. 
speak of God's mutability. There is a change-a change of events, from the first to the second, which is proper to God's own being. ${ }^{63}$

Second, the opposition between the two stages of God's history is genuinely bipolar. God is responsible for nothingness, even as God then overcomes it. God establishes nothingness: in Jüngel's argument, "God gives nothingness a place within being by taking it on himself. In that God identified himself with the dead Jesus, he located nothingness within the divine life."64 This means that the first part of Jüngel's sentence above no less than the second owes to a divine decision - as with the от theological sentence. But by the same token, God gives nothingness a place only so as to determine it, creatively: that is, to overcome it. Again, Jüngel: "In bearing annihilation in himself, God proves himself to be the victor over nothingness." The opposition between God and nothingness is genuine, just as was the opposition of God's wrath through exile and God's greater mercy.

Third and finally, as God's history, the history of Jesus Christ is unrepeatable and unique: utterly $\dot{\varepsilon} \varphi \alpha \dot{\alpha} \pi \xi$. In Barth's phrase, God is actus purus et singularis; "God's being-in-act is a being in a 'particular event' — an event whose singularity consists in the fact that its basis is different from all other events in history" 65 Because of these convergences between Jüngel's gospel summary and the dynamic theological sentence from the от, evangelical historicism may offer a way to underwrite the nonfictiveness of statements about divine mutability—such as Yhwh's greater mercy through exile-while also maintaining divine freedom. In this way, evangelical historicism affords a moment of rapprochement between Religionsgeschichte and theological ontology.

For those like Fretheim who see a divine word "bound up... with every reported word of God in the от"66 rather than available first and foremost in Jesus Christ, insuring divine freedom in Jüngel's way may come at too high an interpretive cost: namely, collapsing the testimony of the от prophets into the story of Jesus. Again, the object of the present essay is only to lay out theological routes that lie open to scholars who wish to see the two disciplines of

63 See Jüngel's intriguing claim: "Changelessness (immutabilitas) would not be a compliment even for God, and the old metaphysics was badly advised when it thought it had to pay this compliment to the divine being. No historical being — and the God who has come into the world in Jesus of Nazareth has, no less than a human creature, a history — can become himself or herself without changing" ("Toward the Heart of the Matter," ChrCent 108 [1991]: 228-33, here 228).

64 Jüngel, $G M W, 219$.

65 McCormack, "The Actuality of God," 215.

66 Fretheim, “God (OT View of)," 605. 
Religionsgeschichte and (от) theology momentarily align — and not ultimately to arbitrate which route is more secure. The results of such an essay will hardly persuade the historian of religion who does not identify with Christian language about God. But for those who do, it is hoped that the present essay opens fresh possibilities for resolving the disconnect they perceive between their two professions.

\section{Conclusion}

A line from an old hymn serves as the epigraph of the present essay. A theological excerpt, it addresses God in second person to hymn God's constancy. It sits rudely juxtaposed with the essay's opening claim that deity change is a stockin-trade of historical scholarship. Since many of us in the theological academy live bilingually in both these forms of discourse, code-switching between the two syntaxes that Gilkey specifies, the present essay explores points along which these two discourses run parallel. Divine changelessness in the hymn openly conflicts with the deity change of Religionsgeschichte. But this essay pursued a moment of complementarity by drawing out the dynamism latent within such an (От) theological statement: in terms of the hymn, that latency resides in the linearity of the "morning by morning" and the novelty of the "new mercies." ${ }^{2}$

67 After all, the hymn paraphrases the exilic poem, Lam 3:22, 23. My thanks to Brent A. Strawn for his perennial exhortation to avoid scholarly bifurcation, as well as for commenting on several drafts of the present essay; to M. Justin Walker for understanding and encouraging the project; and to Logan L. Wilmoth, David C. Strobolakos, Jr., Philip Sumpter, Michael J. Chan, Charles O. Treichler, and Claudia Kern for their generous feedback. Though I discovered it too late to interact with, I also took real encouragement that so formidable and faithful a scholar as Stephen B. Chapman makes some moves comparable to those of the present essay, esp. by coordinating divine self-limitation in the от, Terence Fretheim, Bruce McCormack, and, ultimately, the cross of Jesus Christ ("The Covenant God of Israel: Joshua 8, Divine Concession, and Jesus," in Covenant and Election in Exilic and Post-Exilic Judaism, ed. Nathan MacDonald, FAT II/79 [Tübingen: Mohr Siebeck, 2015], 63-85). 